\title{
LKPD Discussion Activity Terintegrasi Keislaman dengan Pendekatan Pictorial Riddle pada Materi Pecahan
}

\author{
Alin Wahyu Rizkiah ${ }^{1 *}$, Nasir ${ }^{1}$, Komarudin ${ }^{1}$ \\ ${ }^{1}$ Jurusan Pendidikan Matematika, Universitas Islam Negeri Raden Intan Lampung. Jalan Endro \\ Suratmin, Sukarame, Bandar Lampung 35133, Indonesia. \\ ${ }^{*}$ Corresponding Author. E-mail: alinwahyurizkiah@gmail.com
}

Received: 17-11-2017; Revised: 06-01-2018; Accepted : 29-01-2018

\begin{abstract}
Abstrak
Penelitian ini bertujuan untuk mengembangkan serta untuk mengetahui respon guru dan peserta didik terhadap LKPD discussion activity yang terintegrasi nilai-nilai keislaman dengan pendekatan pictorial riddle pada pokok bahasan pecahan, berdasarkan modifikasi pengembangan yang dikemukakan oleh Sugiyono. Teknik analisis data yang digunakan adalah teknik analisis data kualitatif dan kuantitatif. Hasil penelitian pengembangan LKPD dengan tahapan yang dilakukan yaitu terdiri dari 7 tahapan: (1) potensi dan masalah; (2) pengumpulan data; (3) desain produk; (4) validasi produk; (5) revisi produk; (6) uji coba produk dan (7) revisi produk. Validasi dilakukan oleh ahli materi, ahli media dan ahli agama. Uji coba produk dilakukan dalam 2 tahap yaitu uji coba kelompok kecil dan uji coba lapangan. Adapun hasil validasi yang diperoleh dari ahli materi bahwa produk yang dikembangkan telah mecapai kriteria baik dalam aspek kualitas isi, ketepatan cakupan, pendekatan pictorial riddle, dan bahasa. Validasi ahli media menyatakan dalam aspek ukuran, desain kulit, dan desain isi pada LKPD mencapai kriteria baik. Validasi ahli agama Islam pada aspek kualitas isi, aspek bahasa, dan pada aspek penekanan-penekanan materi yang diniliai mencapai kriteria sangat baik, sehingga produk dinyatakan layak digunakan. Respon peserta didik pada uji coba kelompok kecil memperoleh rata-rataskor 91,67 dengan kriteria sangat menarik dan uji coba lapangan memperoleh rata-rata skor 87,67dengan kriteria sangat menarik, respon uji coba juga dilakukan terhadap guru dengan memperoleh rata-rata skor 89,6 dengan kriteria sangat menarik.
\end{abstract}

Kata Kunci: LKPD Discussion Activity, Pictorial Riddle, Nilai-nilai KeIslaman

\begin{abstract}
This study aims to develop and to determine the response of teachers and learners to LKPD discussion activity that integrates Islamic values with a pictorial riddle approach on the fractional subject, based on the modification of development proposed by Sugiyono. Data analysis techniques used are qualitative and quantitative data analysis techniques. Result of research of development of LKPD with stage which is done that consist of 7 stages: (1) potential and problem; (2) data collection; (3) product design; (4) product validation; (5) product revisions; (6) product trial and (7) product revision. Validation is done by material experts, media experts, and religious experts. Product trials were conducted in 2 phases: small group trials and field trials. The validation results obtained from the material experts that the product developed has reached the criteria both in the aspect of quality content, an accuracy of coverage, pictorial riddle approach, and language. Validation of media experts stated in the aspect of size, skin design, and content design on LKPD reach good criteria. The validation of Islamic scholars on the quality aspects of the content, the language aspect, and the material emphases attributed to the criteria are very good, so the product is declared worthy of use. Students' responses in small group trials obtained a mean of 91.67 with very interesting criteria and field trials obtained an average score of 87.67 with very interesting criteria, test responses were also made to teachers with an average score of 89, 6 with very interesting criteria.
\end{abstract}

Keywords: LKPD Discussion Activity, Pictorial Riddle Approach, Fractional 


\section{PENDAHULUAN}

Pada proses pendidikan, pastilah melibatkan pembelajaran. Sukses tidaknya sebuah pendidikan terletak pada proses pembelajaran yang dilakukan dalam kelas (F. G Putra, 2016). Selain itu, kesiapan guru untuk mengenal karakter peserta didik dalam pembelajaran juga merupakan modal dalam penyampaian bahan ajar dan juga menjadi indikator suksesnya pelaksanaan pembelajaran (Sagala, 2013). Pembelajaran di kelas tidak terlepas dari mempelajari matematika.

Matematika merupakan suatu sarana berpikir untuk mengkaji sesuatu secara logis, kritis, rasional dan sistematis agar dapat melatih kemampuan peserta didik supaya terbiasa dalam memecahkan masalah yang terdapat di sekitarnya. Mempelajari matematika tidak terbatas hanya pada memahami konsepnya atau prosedurnya saja, banyak hal yang dapat muncul dari hasil proses pembelajaran matematika (Fredi Ganda Putra, 2017). Peranan matematika sangat penting sebagai dasar logika atau penalaran dan penyelesaian kuantitatif yang dapat gunakan untuk pelajaran lainnya. Oleh karena itu, hendaknya pembelajaran matematika dapat terus ditingkatkan hingga mencapai taraf kualitas terbaik. Pada kenyataannya, matematika selalu dianggap mata pelajaran sangat sulit untuk dipahami. pada umumnya peserta didik hanya menghafalkan rumus untuk mengerjakan soal-soal matematika. Pernyataan yang dikutip menurut Lencher mendeskripsikan bahwa dalam menyelesaikan soal matematika yang bersifat abstrak, akan diperlukan pengetahuan serta pemahaman konsepkonsep yang telah dipelajari sebelumnya. Media yang dikembangkan melalui prosedur yang baik menjadi salah satu alternatif yang dapat dilakukan untuk membantu siswa dalam memahami suatu konsep matematis.
Salah satu media yang dapat digunakan utuk mendukung proses belajar termasuk juga dalam mendukung proses belajar matematika yakni adalah Lembar Kegiaatan Peserta Didik (LKPD) atau juga dikenal dengan Lembar Kegiatan Siswa (LKS) atau worksheet (Beladina, Suyitno, \& Khusni, 2013). LKPD merupakan sarana pembelajaran yang bisa dipakai guru untuk meningkatkan aktivitas peserta didik dalam proses pembelajaran. Pada umumnya, LKPD berisi petunjuk praktikum, percobaan dapat dilakukan dirumah, materi, dan soal-soal latihan maupun semua petunjuk yang dapat mengajak peserta didik beraktivitas dalam proses pembelajaran. LKPD sangat baik dipakai untuk meningkatkan aktivitas peserta didik dalam proses pembelajaran (Herman \& Aslim, 2015).

Berdasarkan studi pendahuluan, bahan ajar sudah cukup tersedia namun komponen LKPD yang dipakai hanya berupa soal-soal dan LKPD tersebut belum menggunakan pendekatan pictorial riddle. Selain itu Peserta didik juga perlu mendapatkan pengetahuan tentang ilmu matematika dalam konteks nilai-nilai keislaman dan kaitannya dalam kehidupan sehari-hari, karena merupakan bentuk aplikasi Kurikulum 2013 sesuai dengan kompetensi inti nomor satu yaitu menghargai dan menghayati ajaran agama yang dianut. Berangkat dari hal ini, untuk itu proses pembelajaran hingga media pembelajaran yang digunakan khususnya pada sekolah-sekolah ataupun perguruan tinggi yang berbasiskan Islam sedang gencarnya dilakukan pengintegrasian nilai keislaman kedalamnya oleh para pendidik maupun calon pendidik, dikarenakan proses pembelajaran ataupun media yang bernilai keislaman selain dapat membantu menumbuhkan sikap yang berkarakter bagi para peserta didik, juga menjadi ciri khas 
tersendiri bagi sekolah-sekolah bahkan hingga perguruan tinggi yang berbasiskan keislaman dibanding dengan sekolah ataupun perguruan tinggi yang bersifat umum (Supriadi, 2015). Sedangkan belum digunakannya pictorial riddle dalam pendekatan pembelajaran ditandai dengan sistem pembelajaran yang kerap kali dipakai yakni metode ceramah dan tanya jawab. Dari hasil wawancara diketahui bahwa kebanyakan peserta didik antusias dengan pelajaran matematika namun antusiasnya saat pembelajaran dilakukan dengan diskusi atau kerja kelompok, tetapi peserta didik mengalami kesulitan untuk memahami materi matematika baik konsep maupun perhitungan atau pengerjaannya akibatnya proses pembelajaran tidak mencapai tujuan. Prestasi belajar yang rendah adalah salah satu adanya kesulitan dalam belajar peserta didik termasuk juga akibat belum terwujudnya suasana pembelajaran yang melibatkan para peserta didik untuk aktif (F. G Putra, 2016), dalam hal ini orang yang bertanggung jawab adalah guru yang seharusnya memahami kesulitan peserta didik lalu memberikan bantuan pemecahannya. Alternatif suatu pembelajaran, yaitu dengan guru memberikan LKPD.

Pictorial riddle adalah salah satu pembelajaran yang termasuk ke dalam pembelajaran inkuiri. Pendekatan Pictorial riddle merupakan salah satu proses pembelajaran yang menggunakan gambar atau peragaan di papan tulis, papan poster, atau layar. lalu guru memberikan pertanyaan yang bersangkutan dengan gambar untuk menumbuhkan motivasi belajar peserta didik dalam diskusi kelompok kecil maupun besar (Resta, Fauzi, \& Yukkifli, 2013).

Berdasarkan uraian di atas, peneliti akan melakukan penelitian yang berjudul "Pengembangan LKPD
Discussion Activity yang Terintegrasi Nilai-nilai Keislaman dengan Pendekatan Pictorial Riddle Pada Pokok Bahasan Pecahan". Penulis berharap dengan dikembangkannya LKPD yang terintegrasi nilai-nilai keislaman dengan pendekatan pictorial riddle ini dapat membantu peserta didik lebih tertarik dan aktif melakukan kegiatan pembelajaran matematika di sekolah sehingga dapat membantu peserta didik untuk mengeksplorasi ide-ide mereka hingga memperoleh pengetahuan baru dengan sendirinya.

\section{METODE PENELITIAN}

Penelitian ini menggunakan metode penelitian dan pengembangan (research and Development). Model pengembangan pada penelitian ini yaitu model Borg and Gall yang telah dimodifikasi oleh Sugiyono meliputi 7 tahap yaitu: 1). Potensi dan Masalah, 2). Mengumpulkan Data, 3). Desain Produk, 4). Validasi Desain, 5). Revisi Desain, 6). Uji Coba Produk, 7). Revisi produk (Sugiyono, 2013). Angket pada penelitian ini digunakan untuk melihat respon peserta didik terhadap produk yang dibuat. Angket menggunakan skala likert seperti pada Tabel 1.

\section{Tabel 1. Skala Likert}

\begin{tabular}{lll}
\hline No & Kriteria & Skor \\
1 & Sangat Baik (SB) & 5 \\
2 & Baik (B) & 4 \\
3 & Cukup (C) & 3 \\
4 & Kurang (K) & 2 \\
5 & Sangat Kurang (SK) & 1 \\
\hline
\end{tabular}

Selanjutnya data hasil perolehan skor diubah dalam bentuk persentase dengan menggunakan rumus berikut:

$$
P=\frac{\text { Jumlah skor pengumpulan }}{\text { jumlah skor kriteria }} \times 100 \%
$$

Keterangan :

P : Persentase kelayakan 
Kemudian hasil persentase angket yang diperoleh dari validasi ahli, lembar respon pendidik, lembar respon peserta didik dikategorikan sesuai dengan interpretasi pada Tabel 2.

Tabel 2. Kelayakan dan kriteria kualitatif

\begin{tabular}{lll}
\hline No & Skor Persentase (\%) & Interpretasi \\
1. & $0 \leq \mathrm{P} \leq 20$ & Sangat Kurang \\
2. & $20<\mathrm{P} \leq 40$ & Kurang \\
3. & $40<\mathrm{P} \leq 60$ & Cukup Baik \\
4. & $60<\mathrm{P} \leq 80$ & Baik \\
5. & $80<\mathrm{P} \leq 100$ & Sangat Baik \\
\hline
\end{tabular}

Berdasarkan data Tabel 2, maka produk pengembangan akan berakhir saat skor penilaian terhadap LKPD ini telah memenuhi syarat kelayakan dengan tingkat kesesuaian materi dan desain, pada pokok bahasan pecahan di kategorikan sangat menarik atau menarik.

\section{HASIL DAN PEMBAHASAN}

Hasil pengembangan yang dilakukan oleh peneliti ini adalah menghasilkan Lembar Kerja Peserta Didik (LKPD) Discussion Activity yang Terintegrasi Nilai-Nilai Keislaman dengan Pendekatan Pictorial Riddle pada Pokok Bahasan Pecahan. Penelitian dan pengembangan ini dilakukan dengan menggunakan prosedur pengembangan menurut sugiyono (2013) yang dilakukan dari tahap 1 hingga tahap 7 . Data hasil setiap tahapan prosedur penelitian dan pengembangan yang dilakukan adalah sebagai berikut:

\section{Potensi dan masalah}

Potensi dalam penelitian dan pengembangan ini adalah mengembangkan LKPD Discussion Activity yang terintegrasi nilai-nilai keislaman dengan pendekatan Pictorial Riddle, dengan basic peserta didik yang secara umum memiliki pengetahuan dan pemahaman nilai-nilai keislaman lebih banyak sehingga bisa dengan mudah mengaitkan materi dengan nilai keislaman, namun guru belum mengembangkannya, sehingga peneliti ingin mengembangkannya.

\section{Mengumpulkan Informasi}

Untuk mengumpulkan informasi peneliti mewawancarai guru dan peserta didik MTs Nurul Islam dan mengmpulkan buku, materi dan jrnal yang berkaitan dengan LKPD.

\section{Desain Produk}

Dalam tahap desain $r \begin{array}{r}\text { produk } \\ \text { pengembangan LKPD }\end{array}$
dengan
riddle. Langkah-langkah penyusunan
desain produk LKPD ini, diantaranya
adalah menyesuaikan $r$ standar
kompetensi dan kompetensi dasar serta
silabus berdasarkan kurikulum K13.

\section{Validasi desian}

Validasi LKPD discussion activity yang terintegrasi nilai-nilai keislaman dengan pendekatan pictorial riddle pada pokok bahasan pecahan dilakukan oleh 7 ahli, yang terdiri dari 3 ahli materi, 2 ahli media, 2 ahli nilai-nilai keislaman. Berdasarkan penilaian validasi ahli materi terhadap dari LKPD discussion activity yang terintegrasi nilai-nilai keislaman dengan pendekatan pictorial riddle pada pokok bahasan pecahan dianalisis 3 aspek yaitu aspek kualitas isi, aspek ketepatan cakupan, pictorial riddle dan bahasa. Pada penilaian validasi ahli media dianalisis 3 aspek yaitu aspek ukuran LKPD, desain kulit LKPD, desain isi LKPD. Pada penilaian validasi ahli nilai-nilai keislaman dianalisis 3 aspek yaitu aspek kualitas isi, aspek bahasa, dan aspek penekananpenekanan materi. 
Desimal, 1 (1), 2018 - 43

Alin Wahyu Rizkiah, Nasir, Komarudin

Pada penelitian ini setelah dilakukan validasi oleh para ahli langkah selanjutnya yaitu revisi desain. Setelah itu, uji coba produk ke peserta didik kelas VII MTs terhadap LKPD discussion activity yang terintegrasi nilai-nilai

keislaman dengan pendekatan pictorial riddle pada pokok bahasan pecahan.

Validasi ahli materi

hasil validasi oleh ahli materi pada produk disajikan dalam bentuk grafik pada Gambar 1.

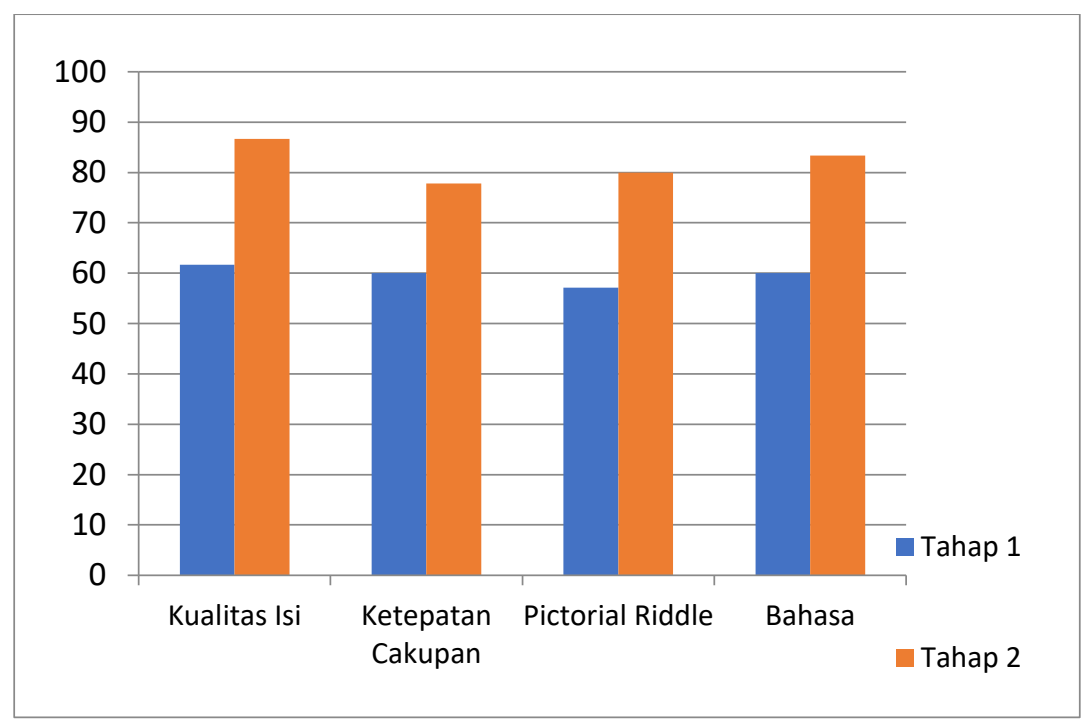

Gambar 1. Hasil Validasi Ahli Materi

Berdasarkan hasil validasi oleh ahli materi pada produk awal diperoleh skor persentase rata-rata $59,70 \%$ dan berada pada kriteria validasi "cukup baik". Setelah produk direvisi dilakukan validasi kembali, diperoleh skor persentase rata-rata $82,44 \%$ dan berada pada criteria sangat "baik", terjadi peningkatan skor setelah produk direvisi (diperbaiki).

\section{Validasi ahli Media}

hasil validasi oleh ahli media pada produk disajikan dalam bentuk grafik berikut: 
Desimal, 1 (1), 2018 - 44

Alin Wahyu Rizkiah, Nasir, Komarudin

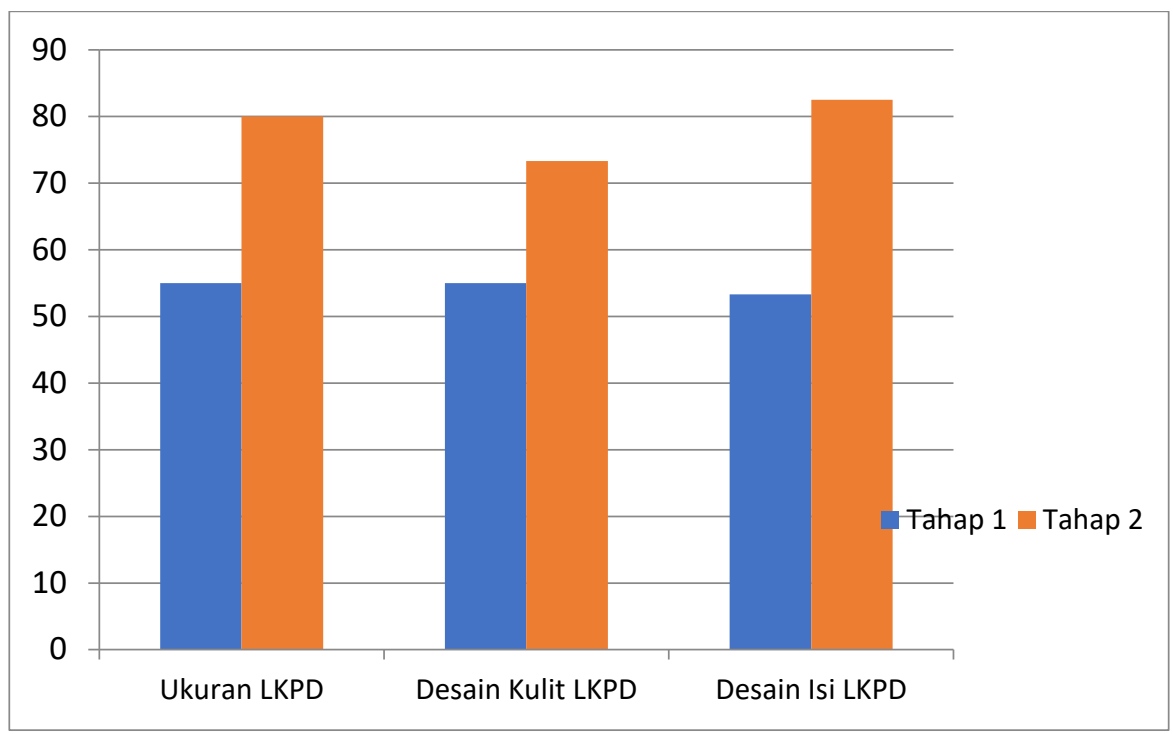

Gambar 2. Hasil Validasi Ahli Media

Berdasarkan hasil validasi oleh ahli materi pada produk awal diperoleh skor persentase rata-rata 54,44 dan berada pada kriteria validasi "cukup baik". Setelah produk direvisi dilakukan validasi kembali, diperoleh skor persentase rata-rata 78,61 dan berada pada kriteria "baik", terjadi peningkatan skor setelah produk direvisi (diperbaiki).

Validasi Ahli Nilai-nilai Keislaman hasil validasi oleh ahli nilai-nilai keislaman pada produk disajikan dalam bentuk grafik berikut:

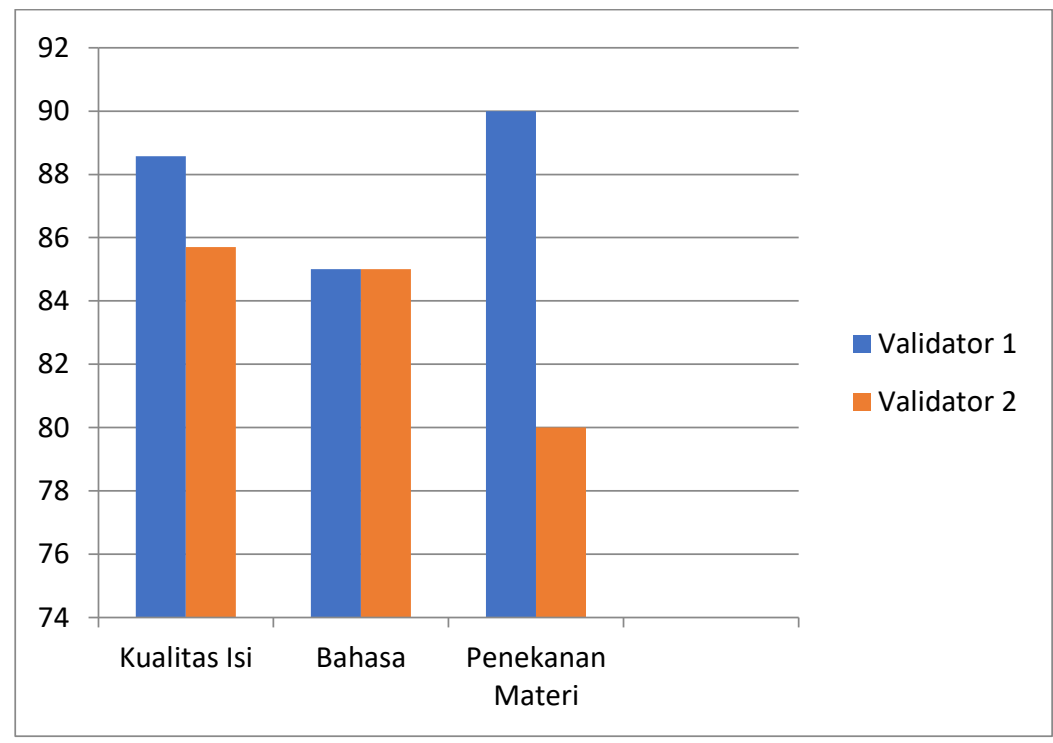

Gambar 3. Hasil Validasi Nilai-nilai Keislaman 
Berdasarkan hasil validasi oleh ahli materi pada produk awal diperoleh skor persentase rata-rata 85,71 dan berada pada kriteria validasi "sangat baik", produk tidak direvisi dikarenakan skor rata-rata sudah tinggi dengan criteria sangat baik.

\section{Revisi Desain}

Setelah desain produk divalidasi melalui penilaian dari ahli materi, ahli media, ahli agama Islam serta guru matematika MTs Nurul Islam, peneliti melakukan revisi terhadap desain produk yang dikembngkan berdasarkan masukan atau saran yang diberikan para ahli.

\section{Uji Coba Produk}

Setelah produk melalui tahap validasi oleh ahli materi, ahli media dan ahli agama Islam serta telah selesai diubah, selanjutnya produk diujikan dengan uji coba kelompok kecil yang terdiri 10 peserta didik, dan uji coba kelompok besar yang terdiri dari 30 peserta didik. Uji coba ini dilakukan di kelas VII MTs Nurul Islam dengan cara memberikan anget untuk mengetahui kemenarikan produk.

\section{Respon Peserta didik}

Uji coba dilakukan 2 tahap yaitu uji coba kelompok kecil dan uji coba lapangan dengan melibatkan 10 peserta didik kelas VII untuk uji coba kelompok kecil dan 30 peserta didik untuk uji coba lapangan dengan cara memberi angket untuk mengetahui respon peserta didik terhadap kemenarikan LKPD.

Uji coba kelompok kecil yang dilakukan di MTs Nurul Islam Lampung Selatan memperoleh skor rata-rata 91,66 dengan kriteria "sangat menarik" dan uji coba lapangan memperoleh skor rata-rata
87,67 dengan kriteria "sangat menarik. Hal ini berarti LKPD yang dikembangkan oleh penulis mempunyai kriteria Sangat Layak digunakan sebagai alat bantu dalam kegiatan belajar mengajar pada materi pecahan untuk kelas VII MTs Nurul Islam.

\section{Respon Pendidik}

Setelah melakukan uji coba kelompok kecil dan uji coba lapangan, kemudian produk diuji cobakan kembali ke pendidik bidang studi matematika. Uji coba pendidik ini dilakukan untuk meyakinkan data dan mengetahui kemenarikan produk. Responden pada uji pendidik ini adalah guru matematika kelas VII MTs Nurul Islam, dengan cara memberikan angket untuk mengetahui respon pendidik terhadap LKPD. Hasil uji coba menghasilkan skor rata-rata 89,6 dengan kriteria "sangat menarik. Hal ini berarti LKPD yang dikembangkan oleh penulis mempunyai kriteria Sangat Layak digunakan sebagai alat bantu dalam kegiatan belajar mengajar pada materi pecahan untuk kelas VII MTs Nurul Islam.

\section{Revisi produk}

Setelah dilakukan uji coba kelompok kecil dan uji coba kelompok besar untuk mengetahui kemenarikan LKPD matematika dengan menggunakan pendekatan pictorial riddle pada materi pecahan, produk dikatakan kemenarikannya sangat tinggi sehingga tidak dilakukan uji coba ulang. Selanjutnya LKPD dapat dimanfaatkan sebagai salah satu sumber belajar bagi peserta didik dan guru di SMP/MTs pada materi pecahan untuk kelas VII.

\section{Kelebihan dan kekurangan produk hasil pengembangan}


Produk pengembangan ini memiliki beberapa kelebihan sebagai berikut: 1) LKPD yang dikembangkan memberikan wawasan pengetahuan baru kepada peserta didik, baik dalam segi materi matematika maupun keterkaitan antara materi pecahan dengan nilai-nilai keislaman; 2) LKPD ini memiliki langkahlangkah pendekatan pictorial riddle pada materi pecahan; 3) LKPD Discussion Activity terintegrasi nilai-nilai keislaman melalui pendekatan pictorial riddle pada materi Pecahan membuat pelajaran menarik; 4) LKPD Discussion Activity yang disusun terdapat ayat-ayat alQur'an, tokoh muslim, latihan soal, sehingga peserta didik memotivasi peserta didik dalam belajar; 5) LKPD Discussion Activity terintegrasi nilai-nilai keislaman melalui pendekatan pictorial riddle pada materi Pecahan efektif jika digunakan secara mandiri maupun kelompok.

Produk pengembangan ini memiliki beberapa kekurangan sebagai berikut: 1) LKPD ini tidak mudah digunakan pada sekolah-sekolah yang memiliki pemahaman nilai-nilai agama Islam lebih banyak; 2) LKPD yang dikembangkan hanya menggunakan pendekatan pictorial riddle pada materi Pecahan.

\section{SIMPULAN DAN SARAN}

Dari Penelitian yang peneliti lakukan dapat diambil kesimpulan yaitu; (1) Lembar Kerja Peserta Didik (LKPD) discusion actvity yang terintegrasi nilainilai keislaman dengan pendekatan pictoril ridle pada pokok bahasan pecahan ini telah dikembangkan dengan menggunakan 7 tahapan yaitu potensi dan masalah, pengumpulan data, desain produk, validasi produk, revisi produk, uji coba produk dan revisi produk. Pada tahap validasi produk yang dilakukan oleh ahli materi dan ahli nilai-nilai keislaman diperolaeh nilai rata-rata dengan kriteria sangat baik, sedangkan untuk ahli media diperoleh nilai rata-rata dengan kriteria baik. (2) Respon peserta didik terhadap LKPD diperoleh nilai ratarata dengan kriteria sangat menarik dan respon guru terhadap LKPD diperoleh nilai rata-rata dengan kriteria sangat menarik. Berdasarkan simpulan yang telah dibuat, maka penulis menyarankan untuk pendidik menggunakan produk yang telah dibuat dalam proses pembelajaran di kelas.

\section{DAFTAR PUSTAKA}

Beladina, N., Suyitno, A., \& Khusni, K. (2013). Keefektifan Model Pembelajaran CORE Berbantuan LKPD Terhadap Kreativitas Matematis Siswa. Unnes Journal of Mathematics Education, 2(3), 34-39.

Herman, H., \& Aslim, A. (2015). Pengembangan LKPD Fisika Tingkat SMA Berbasis Keterampilan Proses Sains. In Prosiding Seminar Nasional Fisika (Vol. IV, pp. 113-118).

Putra, F. G. (2016). Pengaruh Model Pembelajaran Reflektif dengan Pendekatan Matematika Realistik Bernuansa Keislaman terhadap Kemampuan Komunikasi Matematis. Al-Jabar: Jurnal Pendidikan Matematika, 7, 203-210.

Putra, F. G. (2017). Eksperimentasi Pendekatan Kontekstual Berbantuan Hands On Activity (HoA) Terhadap Kemampuan Pemecahan Masalah Matematik. Al-Jabar: Jurnal Pendidikan Matematika, 8(1), 73-80. https://doi.org/10.24042/ajpm.v8i1 .1148

Resta, I. L., Fauzi, A., \& Yukkifli, Y. (2013). Pengaruh Pendekatan Pictorial Riddle Jenis Video Terhadap Hasil Belajar Siswa dalam Pembelajaran Inkuiri pada Materi Gelombang Terintegrasi Bencana Tsunami. Pillar of Physics Education, 1(1), 17-22.

Sagala, S. (2013). Konsep dan makna Pembelajaran. Bandung: Alfabeta. 
Desimal, 1 (1), 2018 - 47

Alin Wahyu Rizkiah, Nasir, Komarudin

Sugiyono. (2013). Metode Penelitian Pendidikan. Bandung: Alfabeta.

Supriadi, N. (2015). Mengembangkan Kemampuan Koneksi Matematis Melalui Buku Ajar Elektronik
Interaktif (BAEI) yang Terintegrasi Nilai-Nilai Keislaman. Al-Jabar: Jurnal Pendidikan Matematika, 6(1), 63-73. 